\title{
Assessment of Upstream Human Intervention Coupled with Climate Change Impact for a Transboundary River Flow Regime: Nile River Basin
}

\author{
Youssef Ahmed $^{1,2} \cdot$ Furat Al-Faraj ${ }^{1,3} \cdot$ Miklas Scholz $^{1,4,5}$ (D) Akram Soliman $^{2}$ \\ Received: 19 September 2018 / Accepted: 2 April 2019 / \\ Published online: 24 April 2019 \\ (C) The Author(s) 2019
}

\begin{abstract}
The aim of this article is to determine how human interventions in upstream countries coupled with drought events are affecting the flow regime of downstream countries using the Nile River basin for illustrative purposes. This has been addressed by assessing climate change in the study area through analyses of precipitation data obtained from the Global Precipitation Climatology Centre (GPCC) and detecting if there is a trend, and subsequently calculating drought events in the main basins impacting on the downstream flow. Then river discharge data were analysed using different hydraulic indices at key stations in the downstream country and measuring the alterations occurring in the flow. The degree of alteration is a function of the number of civil engineering projects being in operation and classified by time windows; pre-alteration is between 1900 and 1925, while the alteration period is between 1933 and 2012. The alteration period was classified into three periods based on the degree of alteration. The findings revealed that there are changes in the river flow regime caused by both changes in the rainfall pattern in addition to the regulation in the upstream countries. There is a direct relationship between the interventions in the upstream countries and changes in the flow regime especially when coupled with drought events. By increasing the water usage upstream, there is an increase in the alteration of the flow downstream. The years between 2000 and 2012 were linked to the highest alterations between the modified years.
\end{abstract}

Keywords Dam construction · Flow pattern alteration · Water resources management $\cdot$ Human intervention $\cdot$ Nile catchment $\cdot$ Riparian country $\cdot$ Rainfall regime change

Miklas Scholz

miklas.scholz@tvrl.lth.se

Extended author information available on the last page of the article 


\section{Introduction}

\subsection{Background}

There is an increasing demand for freshwater to satisfy needs for irrigation, potable water, and industry and hydropower production. Due to upstream countries' interests in abstracting freshwater, there is a need to understand the possible impacts that might affect the flow regime observed in downstream countries (Al-Faraj and Scholz 2014a,b; Rivaes et al. 2015).

River discharge is considered as the main parameter of importance for sustainable water resources management. If discharge dynamics are not well understood, it will lead to improper sustainable water resources management decisions. To achieve an optimum in terms of sustainable water resources management within a transboundary river basin system, alterations in the flow regime should be determined (Al-Faraj and Scholz 2014a,b). The conflict between upstream and downstream areas is exacerbated in transboundary river basins where each country prioritises achieving its own benefits (UNEP 2012).

Lu et al. (2014) stated that dam operations have had significant impacts on the natural flow regimes in most of the world's large rivers. Mwakalila (2008) found that excessive upstream irrigation abstractions for rice irrigation have severely reduced flows downstream. Upstream hydraulic structures and water abstraction schemes have negatively impacted on multiple downstream water usages and considerably modified the flow regime in the downstream state of Iraq (Al-Faraj and Scholz 2014a,b).

Researchers have been interested in measuring changes of river flow regimes occurring due to either climate change or anthropogenic effects (or even both), and subsequently developed methods to assess changes occurring within basin systems. A widely used method is the Indication of Hydrological Alterations to measure the alteration in different areas of northern America, Asia and Africa (Torabi Haghighi and Kløve 2013). Changes in the flow regime were assessed using Indication of Hydrological Alterations to measure the alteration of flow due to dam construction (Mittal et al. 2014). Furthermore, Torabi Haghighi and Kløve (2013) developed the generic River Regime Index to assess the effect of climate change and change in land use on the flow regime.

\subsection{Aim and Objectives}

The aim of this study is to determine how climate change and human-induced actions in upstream regions have affected the flow regime impacting on downstream countries located within a transboundary basin. The Nile river basin has been used as an important example case study. The corresponding objectives are (a) to analyse the flow regime; (b) to assess the changes in the flow regime according to the degree of human intervention; (c) to introduce a methodology for finding metrological data sets in scarce data areas and use it in measuring climate change studies and drought events; and (d) to evaluate the impact of droughts in natural conditions and in intervened conditions. The novel methodology is a step towards filling the gap in knowledge by explaining how climate change coupled with human intervention affects the flow in large river transboundary basins. 


\section{Methodology}

\subsection{Example Basin}

The Nile Basin (Online Resource 1) is one of the largest and most challenging shared river basins. The Nile is the longest $(6700 \mathrm{~km})$ river in the world. It extends over a wide range of latitudes $\left(4^{\circ} \mathrm{S}\right.$ to $\left.31^{\circ} \mathrm{N}\right)$ and longitudes $\left(24^{\circ} \mathrm{E}\right.$ to $\left.40^{\circ} \mathrm{E}\right)$ with a total catchment area of nearly 3,400,000 km² (Sutcliffe and Parks 1999; Onyutha et al. 2016; Multsch et al. 2017).

Egypt is one of the eleven riparian countries sharing the Nile basin (Online Resource 1). Egypt's major water resource is the Nile river with a discharge of 55.5 billion (B) $\mathrm{m}^{3}$ per annum as agreed by the "Nile Water Agreement 1959" (Swain 1997).

The Blue Nile contributes to about $60 \%$ of the total flow at Aswan (Upper Egypt) and is an important river basin for the Eastern Nile countries (Mulat \& Moges, 2014). Ethiopia owns $12 \%$ of the corresponding drainage basin and generates about $86 \%$ of the annual Main Nile river discharge (Melesse, Abtew, \& Setegn, 2014), which is divided as follows (Awulachew et al. 2012): Blue Nile (59\%), Sobat River (14\%) and Atbarah River (13\%). Most construction work took place in the basins of the Blue Nile, Atbarah River, Sobat River and the Main Nile (Online Resources 1 and 2).

The upstream segments of the Nile River and its tributaries have been notably dammed in the upstream riparian countries (Awulachew et al. 2012). There is also a further development plan to increase the number of water control and water diversion facilities (Awulachew et al. 2012). The damming of the Nile River in the upstream riparian countries has started in 1925. The Sennar Dam was constructed for the purposes of irrigation and hydroelectricity generation with a storage capacity of $0.93 \mathrm{Bm}^{3}$. Since its construction, Sudan and other upstream countries have built further dams and hydraulic structures for multi-purpose usages. A giant dam is currently being constructed in Ethiopia.

Online Resource 2 shows the timelines during which the Nile river and its tributaries were subjected to major human interventions in the countries located upstream of Egypt. The data were collected from the Food and Agriculture Organization and have been described, previously (Sutcliffe and Parks 1999; Awulachew et al. 2012; McCartney and Menker Girma 2012).

\subsection{Data Collection}

Long time series of 107 years of monthly flow records (1900-2012; data from 1928 to 1932 cannot be acquired) were observed at the key discharge sites in the northern area of Sudan (upstream of Lake Nasser), at Dongola station, just downstream at the junction between the Blue Nile and the White Nile, and at the beginning of the Main Nile at Tamaniat station were analysed. The data were obtained from the Egyptian Ministry of Water Resources and Irrigation. However, data from 2013 to 2017 could not be acquired as these data sets were collected from databases of the "The Nile Basin" released by the Egyptian Ministry of Water Resources and Irrigation, which are only accessible every 5 yrs.

Measurement data for the Nile basin are incomplete. In the periodicals of the Egyptian Ministry of Water Resources and Irrigation, monthly measurement data of the Nile basin were not distributed uniformly. In Egypt, there are 98 stations distributed all over the country, but only 49 are still operational. Sudan had 131 stations of which only 31 are still working. Ethiopia has only one station in Addis Ababa, which is, however, non-reliable. 
The Nile Basin Initiative (2018) provides incomplete annual Nile data, which are subbasin-based and not country-based. Moreover, the Main Nile basin is linked to only readings from 10 stations, while the Blue Nile basin has annual readings for only 11 stations. There is also a challenge of non-continuity of the station readings for the study period. Furthermore, the Food and Agriculture Organization of the United Nations (FAO) provides monthly data via their Faoclim tool, which were used for cross-checking purposes as well.

Furthermore, to overcome the challenge of relatively sparse data availability, more than one source of processed data has been used, and a comparison and validation exercise has been undertaken between the collected land-based data, the GPCC and the Climate Forecasting System Reanalysis (CFSR) (Online Resources 3 to 5).

\subsection{Trend Investigation}

Linear regression and the Mann-Kendall (M-K) non-parametric test were adapted to detect trends in the data (Duhan et al. 2013). The M-K test advantage is that it can be used in detecting both linear and nonlinear trends. The test was applied using XLSTAT and MATLAB 2015 at a significance level of $5 \%$.

\subsection{Drought Analysis}

Historical drought events were evaluated using the Standardized Precipitation Index (SPI; Yaseen and AL-Timimi 2013). Zarch et al. (2011) categorized the SPI from extremely wet, when the value is greater than 2 , to extremely dry, when it is less than -2 . DrinC software was used to calculate the SPI.

\subsection{Assessment of the Combined Effect of Anthropogenic Pressures and Climate Change}

A set of hydrologic indices was used to determine the degree of alteration in the natural flow regime (pre-damming). The indices are: (a) the annual mean flow; (b) monthly and annual medians; and (c) magnitudes of annual extreme conditions such as the 10th, 25th, 75th and 90th percentiles. The study considers the monthly flow data between 1900 and 2012 at the Dongola hydrometric station in Sudan. In 1925, the first dam in the upstream countries of the Nile River was constructed in Sudan. The period from 1900 to 2012 has been divided into two time windows: Pre-damming (1900-1925) and post-damming (1933-2012). The post regulation period has also been divided into sub-groups based on the degree of human-induced alteration.

The post-damming period has been divided into three time windows: (a) 1933-1963; (b) 1964-1999; and (c) 2000-2012. The division considers the number of dams constructed over the entire post-damming period. In this paper, a methodology proposed by Al-Faraj and Scholz (2014a,b). Flow records were divided into time windows based on the degree of alteration and by applying hydrologic indices to identify alterations in natural flow regime due to the combined influence of climate and upstream damming activities. This method improved the understanding of the cumulative impact of induced forces and climate change over years. The cumulative impacts of human-induced factors and changes of precipitation were evaluated for drought events. 
Flow duration curves (FDC; Sugiyama et al. 2003) were applied for different study periods for both stations. A FDC summarises changes occurring in the flow at a certain location of a catchment (Best et al. 2003; Verma et al. 2016).

\section{Results and Discussion}

\subsection{Historical Trends}

Online Resources 6 to 8 show how data were used. After studying the correlations between the datasets and choosing the GPCC data for this research, the trends in data over time have been analysed. Both parametric and non-parametric trends have been used. Trend analysis was applied for precipitation data at the GPCC stations distributed over the entire basin and for the river discharge at two key locations (Dongola and Tamaniat stations).

Online Resource 9 shows the trend analysis for nine sub-basins of the Nile. The M-K test has been applied for both 1040 stations distributed over the basin and the total area of the subbasins. The number of stations that observed significant trend changes in the precipitation patterns was 183 ( $<20 \%$ of the total). The influence of change in the flow pattern was assessed for the sub-basins after calculating the precipitation using the Theisen polygon method. $P$ values exceeded the significance level. The linear trend for the total sub-basin precipitations was also insignificant $(p<0.05)$.

The months of the three main basins contributing to the river flow (Blue Nile, Atbarah, and Sobat basins) were analysed in terms of linear trends (Table 1). In order to determine how trend changes might affect the total flow volume, the proportional monthly contributions of the annual flow were calculated. The months with the higher contribution in flow for the three basins were August, July and September.

The analysis showed that the months that indicated a decrease in the trend were as follows: For the Blue Nile basin, they were February, July, August and September. For the Atbarah basin, the months were February, June, August and September. Finally, for the Sobat basin, they were February, May and June. Although there was a non-parametric trend detected for the critical months of the flow (August and September), the linear trend showed a very low rate of decrease.

Trend analysis was applied for temperature at the three main basins. The analysis yielded that there was a trend for the maximum temperature for two of the three basins; the Blue Nile basin and the Atbarah basin with $p$ values of 0.008 and 0.003 , respectively.

The river flow at the two observation stations were analysed monthly and annually (Fig. 1, and Online Resources 10 and 11). The p values were less than 0.00001 for the Dongola basin, and 0.0018 and for Tamaniat station. In general, there were significant $(p<0.05)$ trends annually and monthly for both Dongola and Tamaniat stations.

\subsection{Drought Identification}

For the detection of drought occurrence, the SPI was calculated using the precipitation data for the three main basins contributing to the flow of the River Nile. The SPI was computed monthly and annually as an intermediate long-term drought index. Table 2 and Online Resource 12 present the classification according to the SPI as either normal, moderately or severely dry and the corresponding percentages for each period of the time windows regarding the three main basins. 


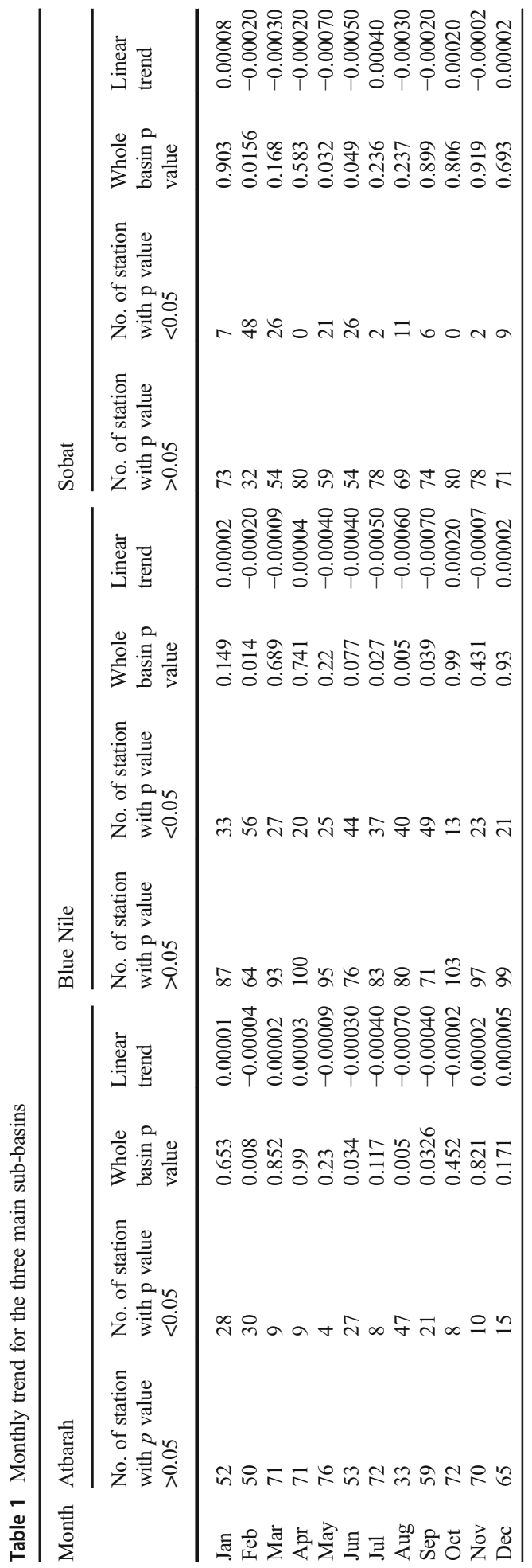




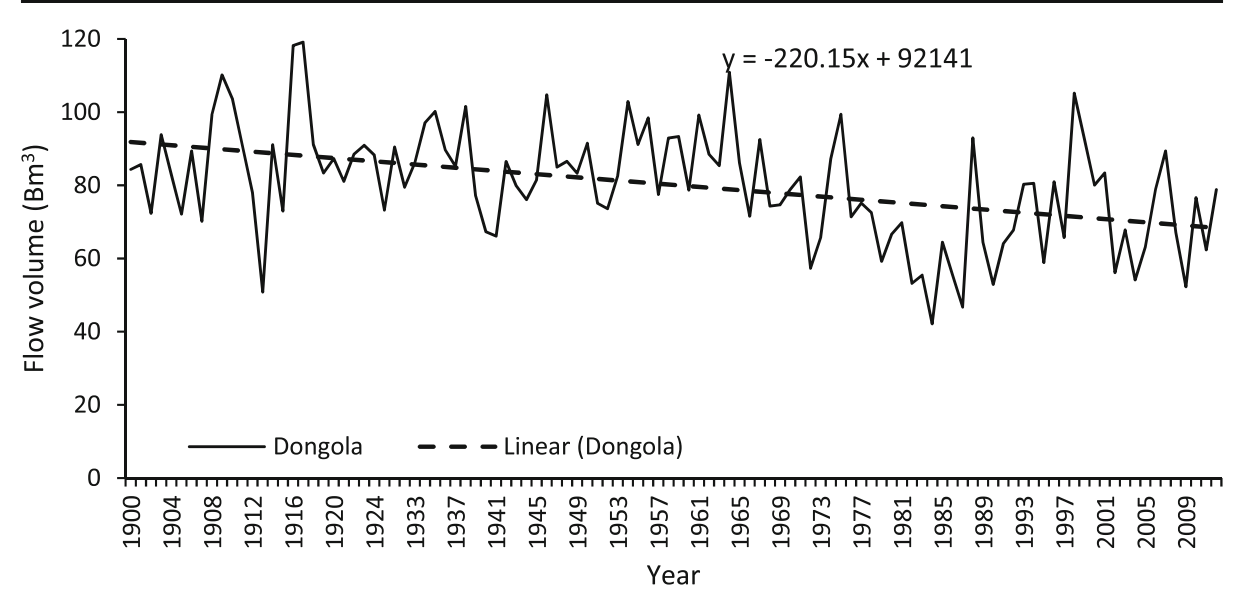

Fig. 1 Linear trend for the Dongola hydrometric station

Table 2 Drought events in the Blue Nile basin and their corresponding \%ages of the precipitation period

\begin{tabular}{|c|c|c|c|c|c|c|c|c|c|c|c|c|}
\hline \multirow[t]{2}{*}{ Month } & \multicolumn{3}{|c|}{ 1901-1925 } & \multicolumn{3}{|c|}{ 1933-1963 } & \multicolumn{3}{|c|}{ 1964-1999 } & \multicolumn{3}{|c|}{$2000-2012$} \\
\hline & $\begin{array}{l}\text { Near- } \\
\text { normal }\end{array}$ & $\begin{array}{l}\text { Mode- } \\
\text { rately } \\
\text { dry }\end{array}$ & $\begin{array}{l}\text { Se- } \\
\text { vere- } \\
\text { ly dry }\end{array}$ & $\begin{array}{l}\text { Near- } \\
\text { normal }\end{array}$ & $\begin{array}{l}\text { Mode- } \\
\text { rately } \\
\text { dry }\end{array}$ & $\begin{array}{l}\text { Se- } \\
\text { vere- } \\
\text { ly dry }\end{array}$ & $\begin{array}{l}\text { Near- } \\
\text { normal }\end{array}$ & $\begin{array}{l}\text { Mode- } \\
\text { rately } \\
\text { dry }\end{array}$ & $\begin{array}{l}\text { Se- } \\
\text { vere- } \\
\text { ly dry }\end{array}$ & $\begin{array}{l}\text { Near- } \\
\text { normal }\end{array}$ & $\begin{array}{l}\text { Mode- } \\
\text { rately } \\
\text { dry }\end{array}$ & $\begin{array}{l}\text { Se- } \\
\text { vere- } \\
\text { ly dry }\end{array}$ \\
\hline Jan & 14 & 5 & 2 & 18 & 7 & 2 & 27 & 4 & 0 & 9 & 3 & 0 \\
\hline Feb & 17 & 1 & 0 & 20 & 3 & 2 & 22 & 4 & 5 & 7 & 3 & 2 \\
\hline Mar & 16 & 3 & 1 & 23 & 2 & 2 & 24 & 2 & 2 & 10 & 0 & 2 \\
\hline Apr & 20 & 1 & 2 & 18 & 4 & 3 & 26 & 3 & 4 & 10 & 0 & 0 \\
\hline May & 18 & 0 & 2 & 25 & 1 & 0 & 29 & 0 & 3 & 7 & 1 & 3 \\
\hline Jun & 18 & 2 & 1 & 23 & 1 & 1 & 27 & 2 & 4 & 9 & 0 & 2 \\
\hline Jul & 18 & 3 & 1 & 20 & 2 & 1 & 22 & 4 & 5 & 8 & 3 & 1 \\
\hline Aug & 16 & 1 & 2 & 21 & 1 & 0 & 25 & 6 & 4 & 13 & 0 & 0 \\
\hline Sep & 16 & 0 & 3 & 21 & 1 & 1 & 27 & 3 & 4 & 12 & 1 & 0 \\
\hline Oct & 19 & 2 & 1 & 23 & 3 & 1 & 18 & 6 & 2 & 8 & 2 & 1 \\
\hline Nov & 19 & 1 & 1 & 21 & 1 & 2 & 23 & 6 & 1 & 11 & 1 & 0 \\
\hline Dec & 18 & 2 & 1 & 22 & 3 & 0 & 22 & 5 & 4 & 9 & 0 & 2 \\
\hline Year & 17 & 1 & 1 & 22 & 0 & 1 & 21 & 8 & 5 & 7 & 5 & 1 \\
\hline \multicolumn{13}{|c|}{$\%$ of precipitation } \\
\hline Jan & 56 & 20 & 8 & 58 & 23 & 6 & 75 & 11 & 0 & 69 & 23 & 0 \\
\hline Feb & 68 & 4 & 0 & 65 & 10 & 6 & 61 & 11 & 14 & 54 & 23 & 15 \\
\hline Mar & 64 & 12 & 4 & 74 & 6 & 6 & 67 & 6 & 6 & 77 & 0 & 15 \\
\hline Apr & 80 & 4 & 8 & 58 & 13 & 10 & 72 & 8 & 11 & 77 & 0 & 0 \\
\hline May & 72 & 0 & 8 & 81 & 3 & 0 & 81 & 0 & 8 & 54 & 8 & 23 \\
\hline Jun & 72 & 8 & 4 & 74 & 3 & 3 & 75 & 6 & 11 & 69 & 0 & 15 \\
\hline Jul & 72 & 12 & 4 & 65 & 6 & 3 & 61 & 11 & 14 & 62 & 23 & 8 \\
\hline Aug & 64 & 4 & 8 & 68 & 3 & 0 & 69 & 17 & 11 & 100 & 0 & 0 \\
\hline Sep & 64 & 0 & 12 & 68 & 3 & 3 & 75 & 8 & 11 & 92 & 8 & 0 \\
\hline Oct & 76 & 8 & 4 & 74 & 10 & 3 & 50 & 17 & 6 & 62 & 15 & 8 \\
\hline Nov & 76 & 4 & 4 & 68 & 3 & 6 & 64 & 17 & 3 & 85 & 8 & 0 \\
\hline Dec & 72 & 8 & 4 & 71 & 10 & 0 & 61 & 14 & 11 & 69 & 0 & 15 \\
\hline Year & 68 & 4 & 4 & 71 & 0 & 3 & 58 & 22 & 14 & 54 & 38 & 8 \\
\hline
\end{tabular}


For the Blue Nile basin, the drought events increased and became more severely over time. Regarding the first two time windows 1901-1925 and 1933-1963, near normal conditions dominated around $70 \%$ of the periods. For the subsequent time windows 1964-1999 and 2000-2012, the near normal conditions decreased to be only around 55\%, while the remaining ones were either moderately or severely dry. The number of the moderately dry and severely dry years for the Blue Nile basin was 23. Moreover, 15 of these years were noted for the period after 1980. Concerning the Atbarah and Sobat basins, the last 32 years suffered severe drought events. These droughts affected the flow volumes of the last to time windows (1964-1999 and 2000-2012).

\subsection{Changes in the Precipitation and Flow Patterns}

The precipitation is neither seasonally nor annually steady (Online Resource 13). As precipitation is the main source of river runoff, there is a direct relationship between climate variability from the perspective of precipitation and river flow. Precipitation irregularities were the only main constrains affecting the change in natural flow conditions between 1900 and 1925. The other study periods (1933-1963, 1964-1999 and 2000-2012) were characterised by changes to flow in comparison to the natural flow period between 1901 and 1925. The main four sub-basins (Blue Nile, Sobat and Atbarah) have experienced changes in the precipitation patterns (Online Resource 13).

The Blue Nile, which is considered as the major contributor to discharge, has seen changes in rainfall patterns. For example, between the mean rainfall from 1901 to 1925 , and the mean rainfall from 1901 to 2012, there was a decrease from $1118 \mathrm{~mm} /$ year to $1105 \mathrm{~mm} /$ year, representing about $1.2 \%$.

The rate of change for the rainfall patterns between the periods 1901-1925 and 1901-2012 were different compared to the rate of flow change at Dongla station for these two time periods. Changes in rainfall for the sub-basins Blue Nile, Sobat and Atbarah were $-1.2 \%$, $1.2 \%$ and $-3.0 \%$, respectively. These changes in rainfall and the contribution of the sub-basins to the river flow led to a decrease in the flow by $2.8 \%$, while the observed changes in flow at Dongola station indicated a decrease by $7.7 \%$. For the changes in rainfall between the periods 1901-1925 and 1933-1963, the Blue Nile, Sobat and Atbarah sub-basin average rainfalls increased by $3.50 \%, 5.60 \%$, and $0.85 \%$. These increases in the rainfall patterns of the three sub-basins should have led to an increase in the amount of flow at Dongola station. However, the contrary was the case, and a decrease in flow by $1.2 \%$ was noted. This shows that there has to be another reason such as human intervention for the decrease of the amount of flow.

The temperature at the Blue Nile was monitored for 34 years only. The corresponding period was divided into two time windows: 1979-1999 and 2000-2012. No extreme changes in temperature were noted. The mean maximum temperature for the first and second time periods were $31.12{ }^{\circ} \mathrm{C}$ and $32.34{ }^{\circ} \mathrm{C}$, respectively. The mean precipitation at Atbara basin increased from $34.2{ }^{\circ} \mathrm{C}$ to $35.3{ }^{\circ} \mathrm{C}$. Atbara basin also witnessed a decrease in the mean maximum value by $0.33{ }^{\circ} \mathrm{C}$.

\subsection{Altered and Unaltered Mean Annual Flow Ratio}

The total flow volume of the whole period (1900-2012) of investigation for Dongola station was between $328.5 \mathrm{~m}^{3} / \mathrm{s}$ and 12,307 m³ $/ \mathrm{s}$. The minimum flow was observed for May 1922 and the maximum value was recorded for September 1998. While for the Tamaniat station, the 
minimum flow was $366.5 \mathrm{~m}^{3} / \mathrm{s}$ (April 1922) and the maximum value was $9484 \mathrm{~m}^{3} / \mathrm{s}$ (September 1917).

The long-term mean flow volume for the unaltered period at Dongola between the years 1900-1925 was $87.8 \mathrm{Bm}^{3} /$ year. For Tamaniat, the mean flow volume for the period 19111925 was $77.3 \mathrm{Bm}^{3} /$ year. Table 3 and Online Resource 14 show the flow for each year of post alteration, the flow volumes as well as their proportions for the unaltered period for both Dongola and Tamaniat stations.

Table 3, Fig. 2 and Online Resources 14 and 15 illustrate the anomaly of the annual mean flow for the altered period compared to the long-term annual flow for the unaltered flow. The

Table 3 Anomaly of the annual mean flow for the altered period compared to the long-term annual flow for the unaltered flow at Dongola

\begin{tabular}{|c|c|c|c|c|c|c|c|}
\hline $\begin{array}{l}\text { Water } \\
\text { year }\end{array}$ & $\begin{array}{l}\text { Flow } \\
\left(\mathrm{m}^{3} / \mathrm{s}\right)\end{array}$ & $\begin{array}{l}\text { Flow } \\
\text { volume } \\
\left(\mathrm{Bm}^{3}\right)\end{array}$ & $\begin{array}{l}\% \text { to the long-term mean } \\
\text { annual flow volume (1900- } \\
1925)\end{array}$ & $\begin{array}{l}\text { Water } \\
\text { year }\end{array}$ & $\begin{array}{l}\text { Flow } \\
\left(\mathrm{m}^{3} / \mathrm{s}\right)\end{array}$ & $\begin{array}{l}\text { Flow } \\
\text { volume } \\
\left(\mathrm{Bm}^{3}\right)\end{array}$ & $\begin{array}{l}\% \text { to the long-term } \\
\text { mean annual flow } \\
\text { volume }(1900-1925)\end{array}$ \\
\hline 1933 & 2769.29 & 86.14 & 98.11 & 1973 & 2115.74 & 65.81 & 74.96 \\
\hline 1934 & 3121.53 & 97.09 & 110.59 & 1974 & 2804.78 & 87.24 & 99.37 \\
\hline 1935 & 3326.00 & 103.45 & 117.84 & 1975 & 3196.37 & 99.42 & 113.24 \\
\hline 1936 & 2883.1 & 89.68 & 102.15 & 1976 & 2295.14 & 71.39 & 81.31 \\
\hline 1937 & 2738.81 & 85.19 & 97.03 & 1977 & 2415.9 & 75.14 & 85.59 \\
\hline 1938 & 3265.05 & 101.56 & 115.68 & 1978 & 2332.95 & 72.56 & 82.65 \\
\hline 1939 & 2477.24 & 77.05 & 87.77 & 1979 & 1903.55 & 59.21 & 67.44 \\
\hline 1940 & 2164.74 & 67.33 & 76.69 & 1980 & 2144.29 & 66.70 & 75.97 \\
\hline 1941 & 2126.16 & 66.13 & 75.33 & 1981 & 2242.67 & 69.76 & 79.46 \\
\hline 1942 & 2780.48 & 86.48 & 98.51 & 1982 & 1709.88 & 53.18 & 60.58 \\
\hline 1943 & 2567.13 & 79.85 & 90.95 & 1983 & 1783.18 & 55.46 & 63.18 \\
\hline 1944 & 2445.6 & 76.07 & 86.65 & 1984 & 1354.55 & 42.13 & 47.99 \\
\hline 1945 & 2616.51 & 81.38 & 92.70 & 1985 & 2071.37 & 64.43 & 73.39 \\
\hline 1946 & 3367.28 & 104.74 & 119.30 & 1986 & 1782.79 & 55.45 & 63.16 \\
\hline 1947 & 2731.87 & 84.97 & 96.79 & 1987 & 1501.93 & 46.72 & 53.21 \\
\hline 1948 & 2782.79 & 86.56 & 98.59 & 1988 & 2988.43 & 92.95 & 105.88 \\
\hline 1949 & 2677.47 & 83.28 & 94.86 & 1989 & 2072.15 & 64.45 & 73.41 \\
\hline 1950 & 2941.36 & 91.49 & 104.21 & 1990 & 1700.23 & 52.88 & 60.24 \\
\hline 1951 & 2414.74 & 75.11 & 85.55 & 1991 & 2057.10 & 63.98 & 72.88 \\
\hline 1952 & 2366.13 & 73.60 & 83.83 & 1992 & 2178.63 & 67.76 & 77.19 \\
\hline 1953 & 2658.56 & 82.69 & 94.19 & 1993 & 2581.40 & 80.29 & 91.46 \\
\hline 1954 & 3306.71 & 102.85 & 117.15 & 1994 & 2589.51 & 80.54 & 91.74 \\
\hline 1955 & 2930.17 & 91.14 & 103.81 & 1995 & 1891.98 & 58.85 & 67.03 \\
\hline 1956 & 3163.97 & 98.41 & 112.10 & 1996 & 2602.62 & 80.95 & 92.21 \\
\hline 1957 & 2491.13 & 77.48 & 88.26 & 1997 & 2112.27 & 65.70 & 74.84 \\
\hline 1958 & 2987.27 & 92.92 & 105.84 & 1998 & 3381.56 & 105.18 & 119.81 \\
\hline 1959 & 3001.54 & 93.36 & 106.34 & 1999 & 2973.38 & 92.48 & 105.34 \\
\hline 1960 & 2529.32 & 78.67 & 89.61 & 2000 & 2572.92 & 80.03 & 91.16 \\
\hline 1961 & 3189.81 & 99.22 & 113.01 & 2001 & 2679.40 & 83.34 & 94.93 \\
\hline 1962 & 2842.98 & 88.43 & 100.72 & 2002 & 1804.40 & 56.12 & 63.93 \\
\hline 1963 & 2744.6 & 85.37 & 97.24 & 2003 & 2180.94 & 67.84 & 77.27 \\
\hline 1964 & 3565.59 & 110.90 & 126.33 & 2004 & 1740.74 & 54.14 & 61.67 \\
\hline 1965 & 2770.45 & 86.17 & 98.15 & 2005 & 2029.71 & 63.13 & 71.91 \\
\hline 1966 & 2299.77 & 71.53 & 81.48 & 2006 & 2537.81 & 78.94 & 89.91 \\
\hline 1967 & 2973.77 & 92.50 & 105.36 & 2007 & 2873.07 & 89.36 & 101.79 \\
\hline 1968 & 2388.89 & 74.30 & 84.64 & 2008 & 2155.86 & 67.06 & 76.38 \\
\hline 1969 & 2400.46 & 74.66 & 85.05 & 2009 & 1680.56 & 52.27 & 59.54 \\
\hline 1970 & 2535.49 & 78.86 & 89.83 & 2010 & 2462.58 & 76.60 & 87.25 \\
\hline 1971 & 2645.45 & 82.28 & 93.73 & 2011 & 2004.24 & 62.34 & 71.01 \\
\hline 1972 & 1842.21 & 57.30 & 65.27 & 2012 & 2534.34 & 78.83 & 89.79 \\
\hline
\end{tabular}


anomalies at Dongola ranged from $48 \%$ observed in 1984 to $126 \%$ in 1964 . For Tamaniat, the minimum and maximum anomalies were $56 \%$ and $133 \%$, respectively. They occurred in the same years as for the Dongola station. According to the study of the SPI, the 1980s suffered from drought, and especially 1984 with an SPI value of -2.2 for Blue basin, -2.6 for Atbarah basin and -1.1 for Sobat basin.

The anomalies in flow rate at Dongola for the periods 1933-1963, 1964-1999 and 20002012 ranged from 75 to $119 \%$, from 48 to $126 \%$, and from 59 to $102 \%$, respectively. The maximum shift in the annual flow volume was between 2000 and 2012. The Tamaniat station anomalies for the same periods were from 78 to $117 \%$, from $56 \%-133 \%$ and from 73 to $120 \%$ in this order.

\subsection{Annual, Monthly Median Flow and Percentiles Anomaly}

The long-term annual median flows for the pre-damming period were $1574 \mathrm{~m}^{3} / \mathrm{s}$ for Dongola and $1595 \mathrm{~m}^{3} / \mathrm{s}$ for Tamaniat. Online Resources 16 and 17 show the anomalies of the median annual flow of the post-damming period compared to the median flow of the natural flow regime at Dongola. For the first alteration period 1933-1963, the flow median varied between $-26 \%$ in the year 1953 and increased by $11.3 \%$ in the year 1934 . For the second time period 1964-1999, the decrease in the median was greater than the one for the previous period, and even the increase in the median was less than the one between 1933 and 1963, where the minimum value represented a decrease in the median by $-39.7 \%$ in year 1995, and an increase in the median by almost $31 \%$ in 1965 . For the last time window 2000-2012, there was a considerable change; all values were below the median flow.

The findings concerning the median flow for the Tamaniat station (Online Resources 9 and 17) were much alike what was observed at Dongola station, except for the period between 1933 and 1963, which witnessed only $1 \mathrm{yr}$ with a positive anomaly (year 1933). For the period between 2000 and 2012, there was also only one positive value of 1.2 for the year 2007 .

Regarding the monthly median flow for Dongola station, the pre-alteration period longterm monthly median varied between $515 \mathrm{~m}^{3} / \mathrm{s}$ in May and $8623 \mathrm{~m}^{3} / \mathrm{s}$ in September as

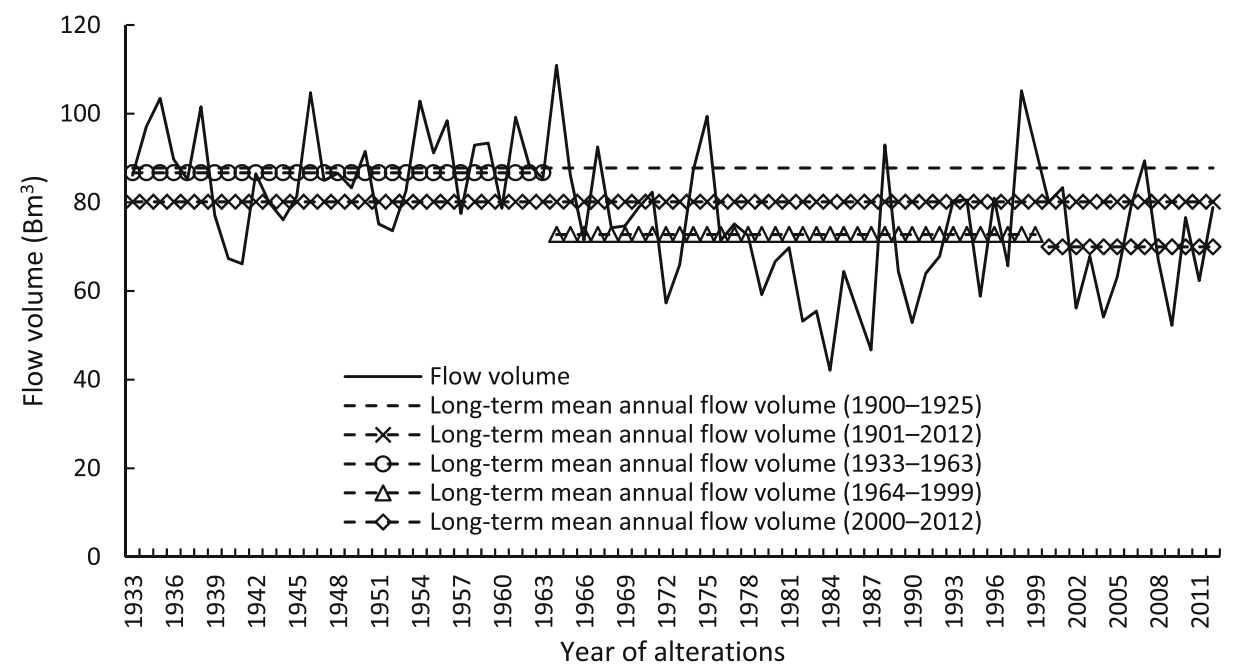

Fig. 2 Annual deviation of altered flow to long-term unaltered flow at Dongola station 
illustrated in Online Resource 17 and Fig. 3. For the first time period 1933-1963, the median ranged between $686 \mathrm{~m}^{3} / \mathrm{s}$ as the minimum measurement in May with an increase in anomaly by $33 \%$. The maximum value was $8708 \mathrm{~m}^{3} / \mathrm{s}$, which represents an increase of $1 \%$ compared to the natural flow condition. For the second period of alteration (1964-1999), the monthly median minimum value was $717 \mathrm{~m}^{3} / \mathrm{s}$ in March, and the maximum value was $6511 \mathrm{~m}^{3} / \mathrm{s}$ in August. Finally, for the high alteration period (2000-2012), the minimum monthly flow was $780 \mathrm{~m}^{3} / \mathrm{s}$ in March and the highest value was $7463 \mathrm{~m}^{3} / \mathrm{s}$ in August. The anomaly for the time windows 1933-1963, 1964-1999 and 2000-2012 ranged between $-12 \%$ and $71 \%,-42 \%$ and $119 \%$, and $-55 \%$ and $106 \%$, respectively.

There were also changes in the median flow at Tamaniat station (Online Resources 17 and 18). The minimum value for the natural flow condition was $567 \mathrm{~m}^{3} / \mathrm{s}$ in April and the maximum was $6752 \mathrm{~m}^{3} / \mathrm{s}$ in September. The anomalies for the time windows 1933-1963, 1964-1999 and 2000-2012 ranged between $-13 \%$ and $65 \%,-34 \%$ and $130 \%$, and $-40 \%$ and $97 \%$, correspondingly.

The median flow represented by the 50th percentile and the other remaining percentiles (10th, 25th, 50th, 75th and 90th percentiles) are considered as important statistical tools to identify the changes of hydrologic characteristics within a basin. The percentiles were calculated for all time span pre- and post-alteration periods (Fig. 4 and Online Resources 19 to 21).

For Dongola station, there was a decrease between the natural condition and the altered period for the flow that was equal to or exceeded the threshold at $90 \%$ for the wet period (Online Resources 20 and 22). For the natural flow condition in September, the 90th percentile value decreased only slightly from $10,571 \mathrm{~m}^{3} / \mathrm{s}$ to $10,424 \mathrm{~m}^{3} / \mathrm{s}$ between 1933 and 1963 . For the other two time periods, there was a considerable decrease in the 90th percentile for September between 1964 and 1999 as well as between 2000 and 2012. This is reflected in the corresponding discharges of $9460 \mathrm{~m}^{3} / \mathrm{s}$ and $8508 \mathrm{~m}^{3} / \mathrm{s}$ in this order. Flows that were equal or exceeded the threshold at $90 \%$ of the time increased for the months after the falling limb of the hydrograph and before the start of the rising limb (from April to June). For example, the 90th percentile was $891 \mathrm{~m}^{3} / \mathrm{s}$ in June, and increased to 1125,1246 and $1507 \mathrm{~m}^{3} / \mathrm{s}$ between 1933 and 1963, 1964-1999 and 2000-2012, respectively.

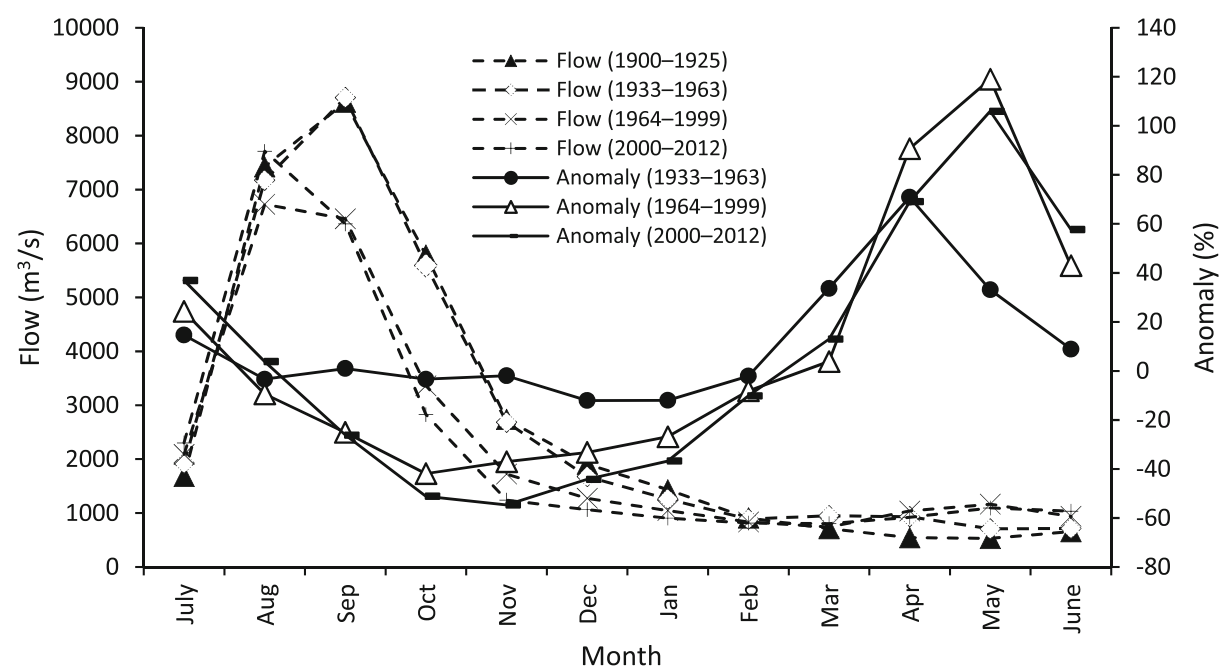

Fig. 3 Long-term monthly median flow and anomaly at Dongola station 

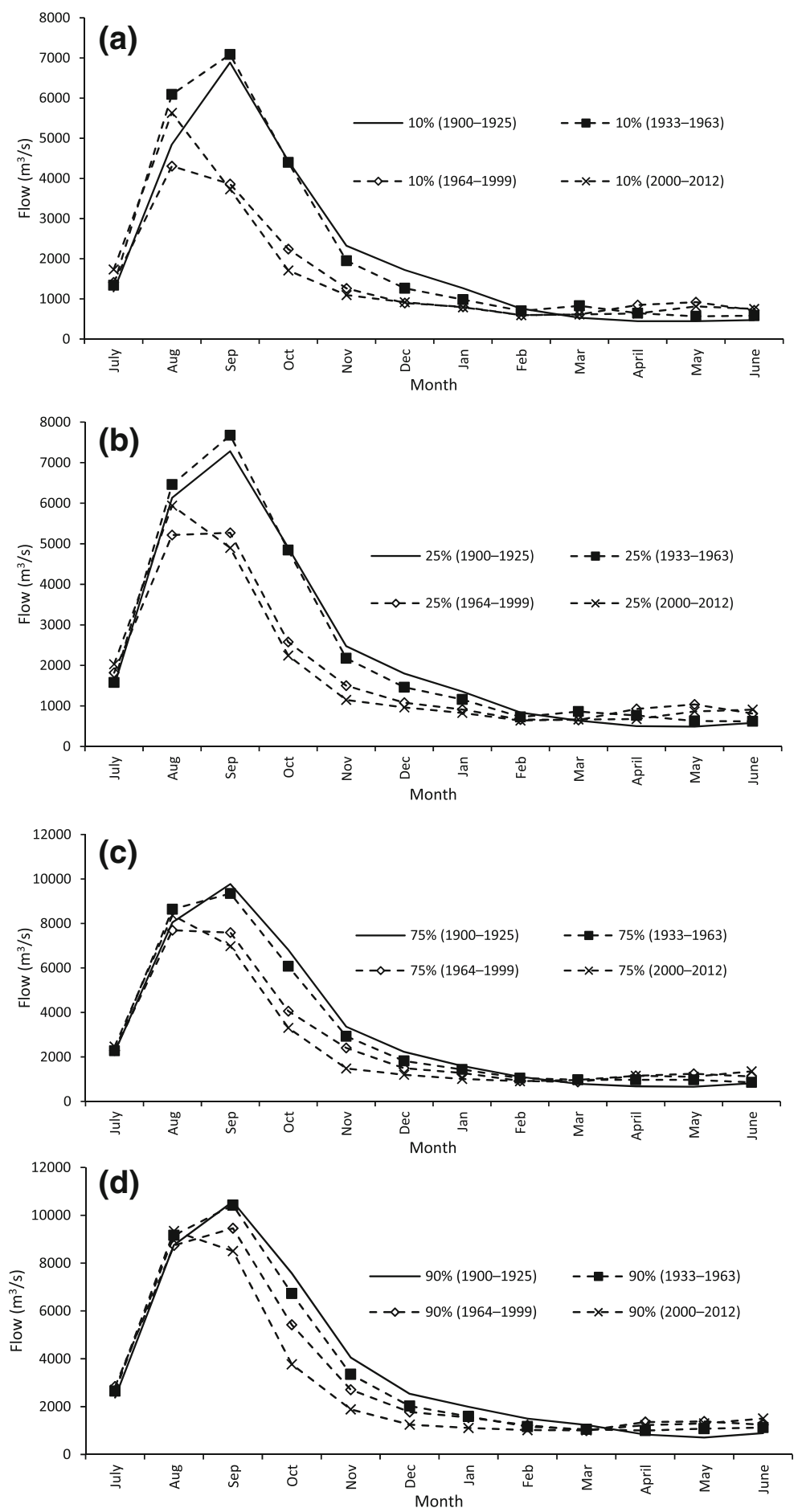

Fig. 4 Percentiles at Dongola for (a) natural flow condition; (b) altered flow from 1933 to 1963; (c) altered flow from 1964 to 1999; and (d) altered flow from 2000 to 2012 
More data and percentile analysis are presented in Online Resources 19 to 23 . For example, Online Resource 21 compares the percentiles of all unaltered and altered time windows. The deformation in the shape of flow shifted from the natural flow to the most altered time period (2000-2012). Concerning the natural flow condition, the difference between the minimum and maximum values for the 10th, 25th, 75th and 90th percentiles were 6441, 6792, 9111 and 9865 $\mathrm{m}^{3} / \mathrm{s}$, respectively. For the years between 1933 and 1963, the 10th and the 25 th percentiles have seen a slight increase in the difference between the minimum and maximum values compared to the natural flow conditions. The 10 th percentile increased by $1.2 \%$ and the 25 th percentile surged by $3.9 \%$. Regarding the 75 th and 90 th percentiles, decreases of $6.8 \%$ and $4.5 \%$, respectively, were noted. For the period from 1964 to 1999 , the difference between the minimum and maximum values for the 10th, 25th, 75th and 90th percentiles decreased by $42 \%, 32 \%, 25 \%$ and $14 \%$, correspondingly. Finally, for the period from 2000 to 2012 , decreases between the minimum and maximum values for the 10th, 25th, 75th and 90th percentiles of $22 \%, 22 \%, 18 \%$ and $16 \%$, respectively, were noted.

The decreases highlighted above indicate that the nature of the flow regime has changed. The hydrograph deformed in the altered conditions, especially from 2000 to 2012, compared to the hydrograph for the natural flow period. One of the concerns linked to the changes in the hydrograph is that the area subjected to flooding by the Nile River will decrease.

\subsection{Changes in FDC}

Online Resource 24 shows the FDC for Dongola and Tamaniat stations. Concerning Dongola station, it was observed that at low percentiles the natural flow conditions and the flow between 1933 and 1963 were alike. For the periods 1964-1999 and 2000-2012, the flow had the same slope with a slight difference in values. When reaching at least $65 \%$, there were differences in the flow for the three altered periods and the natural flow conditions. The three periods had the same slope and the values were almost equal to each other. The FDC had the same profile for both stations. The FDC characteristics and the steady slope for the three altered periods indicated the effect of structures on the flow regime.

\subsection{Validation of Hydrologic Alteration}

The Sennar Dam $\left(0.93 \mathrm{Bm}^{3}\right)$ was the first structure to be constructed upstream (Sudan) of the transboundary basin in 1925. Through the first alteration period from 1933 to 1963, four dams were constructed; two in Sudan, one in Ethiopia and the Owen Falls dam in Uganda, which added considerable storage capacity to the lake (Online Resource 2). The Sennar dam has a storage capacity accounting for $1.06 \%$ of the long-term mean annual unaltered flow volume. The next major construction project resulted in the construction of the Jebel Aulia dam in 1937. By 1953 and 1954, Tis Abay and the Owen Falls dam, respectively, were constructed.

Through the period of first alteration, 12 out of 31 years had annual mean flows equal or greater than the long-term annual mean flow prior alteration. Three of the twelve high flow readings were taken between the construction of the first and second dam, while six of twelve high flow readings were taken after the construction of all dams in this period, which gives an indication that these years were wet ones.

For the second period of alteration, another four dams were constructed between 1964 and 1995. The construction of these dams increased the storage by $6.77 \mathrm{Bm}^{3}$ compared to the first alteration period. In this period, only 7 of 36 years had mean annual flows greater than the 
long-term annual flow for the unaltered period. This period has also suffered a drought represented by the years with the lowest mean annual flows.

The third altered period from 2000 to 2012 has seen the construction of eight dams. Through this time window, only $1 \mathrm{yr}$ had an annual mean flow greater than the long-term annual mean flow for the unaltered period.

The irrigation schemes linked to the study relate to the hydraulic structures constructed. In Sudan, the major irrigation schemes are as follows (UNEP 2007): Gezira and Managil (870,750 ha), New Halfa (152,280 ha), Rahad (121,500 ha), Gash Delta (101,250 ha), Suki (35,235 ha), Tokar Delta (30,780 ha), Guneid Sugar (15,795 ha), Assalaya Sugar (14,175 ha), Sennar Sugar (12,960 ha); Khashm El-Girba (18,225 ha) and Kenana Sugar (45,000 ha).

The Gezira scheme irrigation area reached gradually 0.87 Mha. The area dedicated to irrigation comprised initially 126,000 ha due to the construction of the Sennar dam in 1925 , reaching 420,000 ha by 1950 . After the construction of the Roseiris dam in 1966, the irrigation area for the Gezira and Managil extensions increased the total to 756,000 ha (World Bank 2010). Thereafter, this area increased again to approximately 870,750 ha in 2010.

The New Halfa on the Atbarah River benefits from the water storage of the Khasm el Gibra dam. The Rahad irrigation scheme uses water from the Blue Nile serving the Roseires dam, which began its operation in 1978. Furthermore, Assalya and Kenana are located on the White Nile (Awulachew et al. 2012).

\section{Conclusions and Recommendations}

The study area suffered both from climate change and human construction activities impacting on the flow. This led to partly severe drought events. For example, dams with different purposes in the upstream countries like Sudan and Ethiopia had a considerable impact on the downstream flow regime especially when coupled with climate change within the Nile river basin part located in Egypt. Damming and the evolution of the irrigation schemes in the upstream countries contributed to hydraulic shifts. Findings revealed that the worst case was when the human-induced factors were coupled with drought periods (e.g., during the 1980s).

Regarding the period between 2000 and 2012, the annual hydrologic anomalies in the mean annual flow showed a decrease in the mean value for the altered flow period. Maximum reductions were noted for years suffering from drought and periods characterised by anthropogenic alterations such as dam constructions.

The annual mean flow shifts for the period from 1933 to 1963 ranged between a decrease of $75 \%$ and an increase of $119 \%$ in flow. The long-term annual mean flow volume decreased by 1\%. For the period from 1964 to 1999, seven mean annual flow shifts ranged between a decrease of $48 \%$ and an increase of $126 \%$. The long-term mean annual flow volume for this period was $72.75 \mathrm{Bm}^{3}$. The corresponding decrease was $17 \%$. For the years 2000-2012, the annual mean flow ranged from 59 to $101 \%$. The corresponding flow volume decreased to 70 $\mathrm{Bm}^{3}$.

Only eight of the altered years (1933-2012) have seen an annual median flow greater than the long-term median unaltered flow. The annual median alteration for the three time windows ranged from -26 to $42 \%,-40$ to $31 \%$, and -46 to $-16 \%$ for the periods from 1933 to 1963 , from 1964 to 1999, and from 2000 to 2012, respectively.

For the percentiles, considerable shifts were noticed over time as human-induced factors such as dams and irrigation schemes influenced the percentiles for each time window, if 
compared to the natural flow condition. The maximum values for the percentiles (10th, 25th, 75th and 90th) decreased remarkably during the rainy months and the months with the highest values of the normal flow. The percentiles increased for the dry period, but the rate of the decrease was much greater than the increase.

Hydraulic alterations of the Nile basin are likely to increase in the future. The construction of mega dams such as the Renaissance dam in Ethiopia and the increase of the irrigation schemes will impact significantly on future flow regimes. Moreover, droughts represent a great threat and their effects are exacerbated by the increased upstream use of water.

The authors recommend further research to identify the climate change impacts on river and tributary flows and separate them from different human-induced intervention categories. The impact of change in land use and urban planning should be assessed for different sub-basins in future studies. Also, mitigation measures to decrease the influence of human interventions and climate change in the upstream countries should be researched more.

Acknowledgements The lead author received $\mathrm{PhD}$ studentship funding by the Arab Academy for Science, Technology and Maritime Transport.

\section{Compliance with Ethical Standards}

Conflict of Interest None.

Open Access This article is distributed under the terms of the Creative Commons Attribution 4.0 International License (http://creativecommons.org/licenses/by/4.0/), which permits unrestricted use, distribution, and reproduction in any medium, provided you give appropriate credit to the original author(s) and the source, provide a link to the Creative Commons license, and indicate if changes were made.

\section{References}

Al-Faraj FAM, Scholz M (2014a) Assessment of temporal hydrologic anomalies coupled with drought impact for a transboundary river flow regime : the Diyala watershed case study. J Hydrol 517:64-73. https:/doi. org/10.1016/j.jhydrol.2014.05.021

Al-Faraj FAM, Scholz M (2014b) Impact of upstream anthropogenic river regulation on downstream water availability in transboundary river watersheds. Int J Water Resour Dev 31:28-49

Awulachew SB, Smakhtin V, Molden D, Peden D (2012) Nile River basin: water, agriculture, governance and livelihoods. Routledge, New York

Best AE, Zhang L, McMahon TA, Western AW (2003) Development of a model for predicting the changes in flow duration curves due to altered land use conditions. Modsim 2003 Int Congr Model Simulation, Vols 14 Vol 1 Nat Syst Pt 1; Vol 2 Nat Syst Pt 2; Vol 3 Socio-Economic Syst Vol 4 Gen Syst 861-866

Duhan D, Pandey A, Gahalaut KPS, Pandey RP (2013) Spatial and temporal variability in maximum, minimum and mean air temperatures at Madhya Pradesh in Central India. Comptes Rendus - Geosci 345:3-21. https://doi.org/10.1016/j.crte.2012.10.016

Lu XX, Li S, Kummu M et al (2014) Observed changes in the water flow at Chiang Saen in the lower Mekong: impacts of Chinese dams? Quat Int 336:145-157. https://doi.org/10.1016/j.quaint.2014.02.006

Mittal N, Mishra A, Singh R et al (2014) Flow regime alteration due to anthropogenic and climatic changes in the Kangsabati River, India. Ecohydrol Hydrobiol 14:182-191. https://doi.org/10.1016/j.ecohyd.2014.06.002

Multsch S, Elshamy ME, Batarseh S et al (2017) Improving irrigation efficiency will be insufficient to meet future water demand in the Nile Basin. J Hydrol Reg Stud 12:315-330. https://doi.org/10.1016/j. ejrh.2017.04.007

Onyutha C, Tabari H, Taye MT et al (2016) Analyses of rainfall trends in the Nile River basin. J Hydroenvironment Res 13:36-51. https://doi.org/10.1016/j.jher.2015.09.002 
Rivaes R, Rodríguez-González PM, Albuquerque A et al (2015) Reducing river regulation effects on riparian vegetation using flushing flow regimes. Ecol Eng 81:428-438. https://doi.org/10.1016/j. ecoleng.2015.04.059

Sugiyama H, Vudhivanich V, Whitaker AC, Lorsirirat K (2003) Stochastic flow duration curves for evaluation of flow regimes in rivers. J Am Water Resour Assoc 39:47-58. https://doi.org/10.1111/j.1752-1688.2003.tb01560.x

Sutcliffe JV, Parks YP (1999) The hydrology of the Nile. IAHS Spec Publ 5:192

Swain A (1997) Ethiopia, the Sudan, and Egypt : the Nile River dispute. J Mod Afr Stud 35:675-694

Torabi Haghighi A, Kløve B (2013) Development of a general river regime index (RRI) for intra-annual flow variation based on the unit river concept and flow variation end-points. J Hydrol 503:169-177. https://oi. org/10.1016/j.jhydrol.2013.08.041

UNEP (2007) Sudan Post-Conflict Enviromental Assessment

UNEP (2012) Status Report on The Application of Integrated Approaches to Water Resources Management. Rio de Janeiro

Verma RK, Murthy S, Verma S, Mishra SK (2016) Design flow duration curves for environmental flows estimation in Damodar River basin, India. Appl Water Sci 7:1283-1293. https://doi.org/10.1007/s13201016-0486-0

World Bank (2010) The World Bank and the Gezira Scheme in the Sudan Political Economy of Irrigation Reforms

Yaseen K, AL-Timimi MHA-J (2013) Assessment of spatial and temporal drought in Iraq during the period 1980-2010. IJEE 2:291-302

Zarch MAA, Malekinezhad H, Mobin MH et al (2011) Drought monitoring by reconnaissance drought index (RDI) in Iran. Water Resour Manag 25:3485-3504. https://doi.org/10.1007/s11269-011-9867-1

Publisher's Note Springer Nature remains neutral with regard to jurisdictional claims in published maps and institutional affiliations.

\section{Affiliations}

\section{Youssef Ahmed $^{1,2} \cdot$ Furat Al-Faraj $^{1,3} \cdot$ Miklas Scholz $^{1,4,5} \cdot$ Akram Soliman $^{2}$}

1 School of Computing, Science and Engineering, Civil Engineering Research Group, The University of Salford, Newton Building, Greater Manchester M5 4WT, UK

2 Arab Academy for Science, Technology and Maritime Transport, College of Engineering, Construction and Building Engineering Department, Abu-Qir main Campus, P.O. Box 1029, Miami-Alexandria, Egypt

3 School of Civil Engineering and Built Environment, University of Bolton, Deane Road, Bolton BL3 5AB, UK

4 Division of Water Resources Engineering, Department of Building and Environmental Technology, Faculty of Engineering, Lund University, P.O. Box 118, 22100 Lund, Sweden

5 Department of Civil Engineering Science, School of Civil Engineering and the Built Environment, University of Johannesburg, Kingsway Campus, PO Box 524, Aukland Park, Johannesburg 2006, South Africa 